International Journal of Social Science (IJSS)

Vol.1 Issue.5 February 2022, pp: 733-738

ISSN: 2798-3463 (Printed) | 2798-4079 (Online)

DOI: https://doi.org/10.53625/ijss.v1i5.1317

\title{
ANALYSIS OF THE WORK ENVIRONMENT AND WORK STRESS ITS IMPLICATIONS ON EMPLOYEE PERFORMANCE
}

\author{
By \\ Ni Nyoman Menuh ${ }^{1}$, Ayu Sri Dewi Wahyuni ${ }^{2}$, Ni Ketut Karwini ${ }^{3}$, Ida Bagus Ngurah Wimpascima ${ }^{4}$ \\ ${ }_{1,4}^{1,4}$ Program Studi Kesekretariatan STIMI Handayani, Denpasar \\ ${ }^{2,3}$ Program Studi Manajemen STIMI Handayani, Denpasar \\ Email: 1nyomanmenuh61@gmail.com
}

\begin{tabular}{l}
\hline \hline Article Info \\
\hline Article history: \\
Received Nov 17, 2021 \\
Revised Dec 25, 2021 \\
Accepted Jan 27, 2022 \\
\\
\hline Keywords: \\
Work Environment \\
Work Stress \\
Employee Performance
\end{tabular}

Corresponding Author:

Ni Nyoman Menuh

Program Studi Kesekretariatan

STIMI Handayani

Email: nyomanmenuh61@gmail.com

\begin{abstract}
The work environment must run well and work stress must be managed properly so that employee performance can be achieved according to the duties and functions of an office. The purpose of this study was to determine the analysis of the work environment and work stress and their implications for employee performance at the Bali and Nusra Ecoregional Development Control Center Office. The type of data used in this study is qualitative and quantitative data with primary data sources and using data analysis techniques, namely classical assumption test, multiple linear regression analysis and hypothesis testing. The results of this study indicate that the work environment has a significant positive effect on employee performance and work stress has a significant negative effect on employee performance.
\end{abstract}

This is an open access article under the $\mathrm{CCBY}$-SA license.

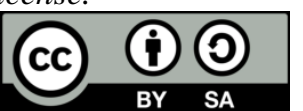

\section{INTRODUCTION}

The work environment is one of the factors that determine employee performance so that every company must have an appropriate work environment for the continuity of employees' work to be able to improve employee performance (Lestary and Harmon, 2017). Based on the results of observations that have been made, the working environment of the Bali and Nusa Tenggara Ecoregion Development Control Center has not supported employees to work comfortably, it can be seen from the physical work environment such as the presence of several unorganized room arrangements, inadequate office facilities such as temperature the room is uncertain in some of the employee's workspace caused by damage to several room temperature settings. Indications of low employee performance at the Bali and Nusa Tenggara Ecoregional Development Control Center Office include: employees are less agile in completing work, employees feel pressed for time in completing work, the work environment is not conducive and there is pressure from superiors.

Research by Narasuci et al (2018) states that the work environment has a significant positive effect on the performance of lecturers at the State Polytechnic of Malang, Indonesia. Kristianti's research (2019) suggests that the work environment has a positive and significant effect on the performance of UD employees. Pratama Karya Kediri. The results of research by Rumawas (2016), Wijaya (2017), Supriyanto (2020) and Tolu (2021) state that the work environment has a significant positive effect on employee performance but in a study conducted by Samson, et al (2015) stated that that the physical aspect of the work environment has no significant effect on the work activities of Commercial Bank employees in Nakuru City, Kenya. This means the inclusion of ergonomic features in the furniture; Adequate lighting and ventilation facilities as well as the availability of work space are not significant factors on the performance of commercial bank employees.

Cross (2019) states that work stress can affect employee performance when stress is not handled properly, absenteeism, turnover and medical compensation increase and productivity decreases. To achieve peak performance, stress must be managed effectively, with the negative effects of stress minimized. The fact that most employees think about leaving their jobs and feel that the organization does not care about them is a reflection of great dissatisfaction 
which undoubtedly lowers performance. Organizations must conduct a needs assessment for the Employee Assistance Program. An Employee Assistance Program should be introduced for early identification and intervention on problems so that performance levels will increase. The results of the research by Shahid et al (2011) show that all stress components cause great stress to bankers and then reduce their performance. The results obtained in the research of Steven and Arif (2020) show that work stress has a significant negative effect on the performance of Telkom Witel North Jakarta employees. The results of a different study, namely the results of Kristianti's research (2019) stated that work stress had a positive and insignificant effect on the performance of UD employees. Pratama Karya Kediri and Martini (2018) with research results work stress has a negative but not significant effect on employee performance at Hotel Mahogany Mumbul Bali.

The existence of discrepancies in the results of previous studies motivates to conduct re-examination with the aim of knowing the analysis of the influence of the work environment and work stress and its implications for employee performance at the Bali and Nusra Ecoregion Development Control Center Office.

\section{Theoretical Foundation}

\section{1) Employee Performance}

Work performance is the work process and work of an employee to achieve the expected goals (Wahyuni et al., 2014). According to Mangkunegara (2006), performance is the result of work in quality and quantity carried out by an employee for the implementation of the tasks and responsibilities given. Supriyanto et al. (2020) adds that performance is a real behavior that is shown in the performance of each employee based on his role in the company, where employees are very important in the company's efforts to achieve its goals.

\section{2) Work Environment}

The work environment is a place where there are a number of groups in which there are several supporting facilities to achieve company goals in accordance with the company's vision and mission (Sedarmayanti, 2013). Mangkunegara (2013) states that the work environment is all aspects of physical work, work psychology, and work regulations that can affect job satisfaction and productivity achievement. Heizer and Render (2015) describe the work environment as the physical environment in which employees work that can affect their performance, safety and quality of work life. Pawirosumarto et al. (2017) stated that the work environment is a place where all employees can carry out activities, where they can have a positive or negative impact on employees to achieve the goals that have been set.

\section{3) Work Stress}

Griffin and Moorhead (2013) define stress as a person's adaptive response to stimuli that place excessive psychological or physical demands on him. Mangkunegara (2013) reveals work stress is caused by the workload that is felt too heavy, the absence of work supervision, the work time given is quite dense, the work environment is not good, there are work conflicts and there are differences in assessing between leaders and employees.

\section{Thinking Framework}

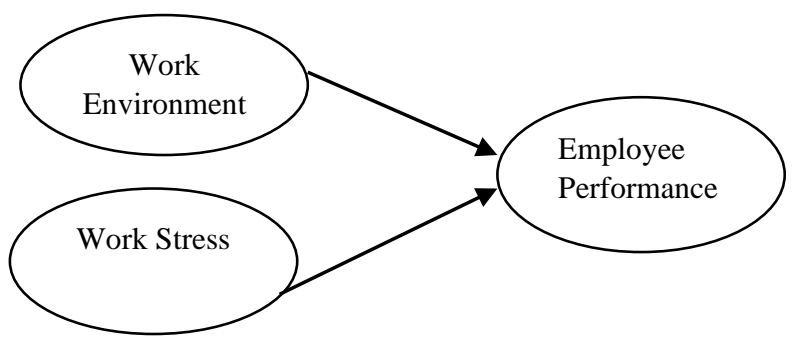

\section{Research Hypothesis}

Figure 1. Thinking Framework

Based on the background and theory as well as the results of previous research, the following hypotheses can be formulated:

H1: The work environment has positive and significant implications for employee performance at the Bali and Nusa Tenggara Ecoregion Development Control Center Office.

$\mathrm{H} 2$ : Work stress has negative and significant implications for employee performance at the Bali and Nusa Tenggara Ecoregion Development Control Center Office.

\section{RESEARCH METHOD}


International Journal of Social Science (IJSS)

Vol.1 Issue.5 February 2022, pp: 733-738

ISSN: 2798-3463 (Printed) | 2798-4079 (Online)

DOI: https://doi.org/10.53625/ijjss.v1i5.1317

This research was conducted at the Bali and Nusa Tenggara Ecoregion Development Control Center Office with the research objects being the Work Environment (X1), Work Stress (X2) and Employee Performance (Y) at the Bali and Nusa Tenggara Ecoregion Development Control Center Office. The type of data used is qualitative data obtained from research results, namely the results of interviews with employees and quantitative data, namely the number of employees and data or questionnaire results scores. The data sources used are primary data, in the form of interviews and the results of filling out questionnaires regarding the work environment, work stress, and employee performance at the Bali and Nusa Tenggara Ecoregion Development Control Center Office in Denpasar. Data collection techniques used are: observation, interviews, documentation and questionnaires. Questionnaires were given to 87 employees of the Bali and Nusa Tenggara Ecoregion Development Control Center Office. The data analysis techniques used are: validity and reliability test, classical assumption test, multiple linear regression analysis and hypothesis testing.

\section{RESULTS AND ANALYSIS}

3.1. Characteristics of Respondents by Age and Gender

Based on the results of the questionnaire, it can be explained that most of the respondents aged 31-40 years are 40 people (46\%), age 41-55 years are 26 people (29.9\%) and the smallest number is 20-30 years, totaling 21 people $(24,1 \%)$. Based on gender, information was obtained that most of the respondents at the Bali \& Nusa Tenggara Ecoregional Development Control Center Office were male, namely 44 people (50.6\%) while the remaining 43 people $(49.4 \%)$ were female.

\subsection{Validity and Reliability Test}

Based on the recapitulation of the calculation results of the product moment correlation value of each statement item, the results obtained are above 0.3. This means that all statement items in the questionnaire are said to be valid. Based on the recapitulation of the results of the calculation of Cronbach's alpha value of each variable, the results obtained that the amount is above 0.60 means that all statements in the questionnaire are said to be reliable.

\subsection{Classic assumption test}

\section{a. Normality test}

Based on the results of the analysis, it can be seen that the significance value for the unstandardized residue is 0.063 , which is greater than 0.05 , so it can be concluded that the variables are normally distributed.

\section{b. Multicollinearity Test}

Based on the results of the analysis, it can be seen that the value of the variance inflation factor (VIF) of the two variables, namely the work environment and work stress, is 2.671 which is smaller than 10 , and the tolerance of 0.374 is more than 0.1 , so it can be concluded that there is no multicollinearity problem between independent variables.

\section{c. Heteroscedasticity Test}

Based on the results of the analysis, it can be seen that the plot graph pattern between the predicted ZPRED values and the residual SRESID is spread out within the limits of the predicted $Y$ values and the real $Y$ values, and there is no data outside these limits. This indicates that there is no heteroscedasticity to the research data.

\subsection{Multiple Linear Regression Analysis}

To answer research problems and test hypotheses, multiple regression analysis is used. The results of the analysis obtained can be seen in Table 1 below:

Table 1. Multiple Linear Regression Results 


\section{Coefficients}

\begin{tabular}{|c|c|c|c|c|c|c|}
\hline \multirow[b]{2}{*}{ Model } & & \multicolumn{2}{|c|}{$\begin{array}{c}\text { Unstandardized } \\
\text { Coefficients }\end{array}$} & \multirow{2}{*}{$\begin{array}{c}\text { Standardized } \\
\text { Coefficients }\end{array}$} & \multirow[b]{2}{*}{$\mathrm{t}$} & \multirow[b]{2}{*}{ Sig. } \\
\hline & & B & Std. Error & & & \\
\hline 1 & (Constant) & 43,873 & 2,338 & & 18,761 &, 000 \\
\hline & $\mathrm{X} 1$ & 181 & ,033 & 474 & 5,427 & , 000 \\
\hline & $\mathrm{X} 2$ &,- 178 & ,035 &,- 448 & $-5,129$ & , 000 \\
\hline
\end{tabular}

a. Dependent Variable: $Y$

Source: Data processing results, 2021

Based on the values of a, b1, b2, the equation of the multiple linear regression line between work environment and work stress on performance is obtained:

$\mathrm{Y}=43,873+0,181 \mathrm{X}_{1}-0,178 \mathrm{X}_{2}$

The work environment coefficient gives a value of 0.181 which means that if the work environment is getting better with the assumption that other variables are fixed, the employee's performance will increase. The work stress coefficient gives a value of -0.178 which means that if the work stress is higher with the assumption that other variables are fixed, the employee's performance will decrease.

\subsection{Statistical $\mathbf{t}$ test ( $\mathrm{t}$ test)}

\section{The Implication of Work Environment on Employee Performance}

The b1X1 regression coefficient of 0.181 means that any increase in attention to the work environment can improve performance, thus it can be concluded that the work environment has a positive impact on employee performance at the Bali and Nusa Tenggara Ecoregional Development Control Center Office. This is confirmed in the first hypothesis testing shows the results that the value of Sig. $t=0.000(p<0.05)$. This shows that Ho is rejected and $\mathrm{Ha}$ accepts so that it is declared to have a significant effect. The results of this study are supported by previous research conducted by Pratama (2019), Supriyanto (2020) and Tolu (2021). stated that the work environment had a significant positive effect on employee performance but in a study conducted by Samson, et al (2015) stated that the physical aspect of the work environment had no significant effect on employee work activities.

\section{Work Stress Implications for Employee Performance}

The b2X2 regression coefficient of -0.178 means that any increase in attention to work stress can reduce performance, so it can be concluded that work stress has negative implications on the performance of the employees of the Bali and Nusa Tenggara Ecoregional Development Control Center. This is confirmed in hypothesis testing, showing the results that Sig. $t=0.000(p<0.05)$. This indicates that Ho is rejected and accepts Ha. This means that there are negative and partially significant implications between work stress and employee performance at the Bali and Nusa Tenggara Ecoregional Development Control Center Office. The results of this study are supported by previous research conducted by Shahid et al (2011), Steven and Arif (2020) but differs from the results of Kristianti's research (2019) which states that work stress has a positive and insignificant effect on the performance of UD employees. Pratama Karya Kediri and Martini (2018) with the results of research that work stress has a negative but not significant effect on employee performance at Hotel Mahogany Mumbul Bali.

\section{CONCLUSION}

Based on the results of the analysis and discussion described in the previous chapter, the following conclusions can be drawn: (1) The work environment has positive and significant implications for employee performance at the Bali and Nusa Tenggara Ecoregional Development Control Center Office; (2) Work stress has negative and significant implications on employee performance at the Bali and Nusa Tenggara Ecoregional Development Control Center Office. This means that an increase in work stress will cause a decrease in performance. Based on the discussion that has been described, the researchers can provide the following suggestions: (1) The head of the Bali and Nusa Tenggara Ecoregion Development Control Center should pay attention to good communication between employees and leaders so that they can complete their duties and responsibilities properly; (2) The head of the Bali and Nusa Tenggara Ecoregion Development Control Center should pay attention to employee work stress so that it does not increase which can lead to a decrease in employee performance potential.

\section{REFERENCES}


International Journal of Social Science (IJSS)

Vol.1 Issue.5 February 2022, pp: 733-738

ISSN: 2798-3463 (Printed) | 2798-4079 (Online)

DOI: https://doi.org/10.53625/ijss.v1i5.1317

[1] Lestary, Lyta, and Harmon Chaniago. "Pengaruh Lingkungan Kerja Terhadap Kinerja Karyawan." Jurnal Riset Bisnis Dan Investasi, Vo. 3 no. 2, pp. 94-103. 2017.

[2] Narasuci, Win, Margono Setiawan, and Noermijati Noermijati. "Effect of work environment on lecturer performance mediated by work motivation and job satisfaction." Jurnal Aplikasi Manajemen, Vol. 16, No .4, pp. 645-653. 2018.

[3] Kristanti, Desi, and Ria Lestari Pangastuti. "Effect Of Work Stress, Work Motivation, And Work Environment To Employee Performance Production Part: Case Study at UD. Pratama Karya Kota Kediri." Business and Finance Journal, Vol. 4, No. 2, pp. 105-114. 2019.

[4] Rumawas, Wehelmina. "Analisis Faktor Motivasi Dan Lingkungan Kerja Yang Berpengaruh Terhadap Kinerja Pegawai Pemerintahan Di Kecamatan Tomohon Barat." Jurnal Logos Spectrum. 2015.

[5] Wijaya, Hendry, and Emi Susanty. "Pengaruh lingkungan kerja terhadap kinerja pegawai pada instansi pemerintah daerah kabupaten musi banyuasin (studi kasus dinas pertambangan dan energi kabupaten musi banyuasin)." Jurnal Ecoment Global: Kajian Bisnis dan Manajemen, Vol. 2, No.1, pp. 40-50. 2017.

[6] Supriyanto, Achmad Sani, and Vivin Maharani Ekowati. "Linking work environment to employee performance: the mediating role of work discipline." BISMA (Bisnis dan Manajemen) 13.1 14-25. 2020.

[7] Tolu, Angelique, et al., "Pengaruh Gaya Kepemimpinan, Lingkungan Kerja, dan Motivasi Kerja Terhadap Kinerja Pegawai”. Jurnal Administrasi Bisnis (JAB), Vol. 11. No. 1, pp. 7-13, 2021.

[8] Samson, Gitahi Njenga; Waiganjo, Maina: Koima, Joel. Effect of Workplace Environment on the Performance of Commercial Banks Employees in Nakuru Town. International Journal of Managerial Studies and Research (IJMSR). 3(12). Pp. 76-89. 2015.

[9] Cross Ogohi Daniel. "Effects of job stress on employee's performance". International Journal of Business, Management and Social Research, 06(02), pp. 375-382. 2019.

[10] Shahid, Muhammad Naeem, et al. "Work stress and employee performance in banking sector evidence from district Faisalabad, Pakistan." Asian Journal of Business and Management Sciences, Vol. 1.7, pp. 38-47. 2011.

[11] Steven, Hartono Jessie, and Arif Partono Prasetio. "Pengaruh Stres Kerja Dan Kepuasan Kerja Terhadap Kinerja Karyawan." Jurnal Penelitian IPTEKS 5.1 (2020): 78-88.

[12] Kristanti, D., \& Pangastuti, R. L. Effect Of Work Stress, Work Motivation, And Work Environment To Employee Performance Production Part: Case Study at UD. Pratama Karya Kota Kediri. Business and Finance Journal, 4(2), pp. 105-114. 2019.

[13] Martini, Luh Kadek Budi. "The Effect of Job Stress and Workload on Employee Performance at Hotel Mahogany Mumbul Bali." Jurnal Ekonomi \& Bisnis JAGADITHA 5.1, pp. 41-45. 2018.

[14] Wahyuni, Dwi. "Pengaruh Pengembangan Karier Terhadap Prestasi Kerja Karyawan (Studi pada Karyawan Tetap PT. Astra International, Tbk Daihatsu Malang)." Jurnal Administrasi Bisnis 8.1. 2014.

[15] Mangkunegara, A.P. Evaluasi Kinerja SDM. Bandung: PT RefikaAditama. 2006.

[16] Supriyanto, A. S.,Ekowati,V.M., \& Maghfuroh, U.. Do Organizational Citizenship Behaviour and Work Satisfaction Mediates the Relationship between Spiritual Leadership and Employee Performance?Management Science Letters, 10(5), 1107-1114. 2020.

[17] Sedarmayanti. Manajemen Sumber Daya Manusia. Bandung: Refika. 2013.

[18] Mangkunegara, A.P. Manajemen Sumber Daya Manusia Perusahaan. Bandung: Remaja Rosdakarya. 2013.

[19] Heizer, J, \& Render, B. Manajemen Operasi: Manajemen Keberlangsungan dan Rantai Pasokan. Edisi 11. Jakarta: Penerbit Salemba Empat. 2015.

[20] Pawirosumarto, S., Sarjana, P. K., \&Gunawan, R. The Effect of Work Environment, Leadership Style, and Organizational Culture Towards Job Satisfaction and its Implication Towards Employee Performance in Parador Hotels and Resorts, Indonesia. International Journal of Law and Management, 59(6), 1337-1358. 2017.

[21] Griffin, R. W., \& Moorhead, G. Organizational Behavior Managing People and Organizations. SouthWestern: Michael Schenk. 2013. 
